\title{
ANALISIS PENINGKATAN KUALITAS DAN STRATEGI PEMASARAN DALAM RANGKA MENINGKATKAN PENDAPATAN PERAJIN KAIN TENUN SONGKET DI DESA GUNUNG BATU KECAMATAN OGAN KOMERING ULU TIMUR
}

\author{
Luis Marnisah'1), Endah Dewi Purnamasari ${ }^{2)}$ \\ 1)2) Manajemen Universitas Indo Global Mandiri \\ Jl. Jendral Sudirman no. 629 Km 4, Kode Pos : 30129 \\ E-mail: luismarnisah@uigm.ac.id ${ }^{1}$, endahdps@uigm.ac.id ${ }^{2}$ )
}

\begin{abstract}
ABSTRAK
Songket yang terdapat di Palembang terletak di Desa Gunung Batu, Kecamatan Cempaka, Kabupaten OKU Timur, Palembang. Sentra tersebut sudah berjalan puluhan tahun dan terdapat \pm 50 perajin wanita yang memproduksi kain tenun Songket. Para perajin industri rumahan dan terdiri dari beberapa kelompok usaha. Hasil produksinya berkualitas rendah dengan harga berkisar antara Rp. 500.000,- - Rp. 1.000.000,-/ helai. Sebagian besar hasil produksinya dipasarkan ke pasar-pasar di kota Palembang, misalnya ke pasar Hero. Tujuan melakukan kemitraan dengan kelompok usaha kain tenun Songket kelompok Aisyah dan Ayu Ning tersebut untuk membina para perajin, khususnya perihal ketrampilan teknis dan teknik pemasaran baru yang lebih sesuai dengan situasi dan kondisi pasar dan pembeli saat ini. Kondisi usaha mitra saat ini memproduksi jenis kain tenun Songket kualitas rendah sehingga keuntungan mitra maupun pendapatan perajinnya pun minim. Nilai jual yang tinggi terletak pada motif yang rumit dan kualitas bahan baku yang digunakan, misalnya benang sutra atau emas. Namun jenis produk kedua mitra bersifat produksi massal dan segmen pasarnya masyarakat bawah. Oleh karena itu, melalui program kemitraan IbM ini diharapkan dapat meningkatkan kualitas produk dan marjin keuntungan mitra dan perajinnya. Target khusus yang ingin dicapai oleh kemitraan ini adalah meningkatkan jumlah perajin yang saat ini mengalami kesulitan mendapatkan tenaga perajin dikarenakan upah yang minim sedangkan pekerjaannya rumit dan harus teliti. Melalui pelatihan/workshop keterampilan menenun tersebut diharapkan dapat meningkatkan ketertarikan terhadap pekerjaan kerajinan tenun Songket. Metode yang akan dilaksanakan adalah metode eksperimental yaitu melakukan eksperimen melalui pelatihan/workshop ketrampilan teknis menenun dan menggunakan medium web sebagai medium on line marketing.
\end{abstract}

Kata kunci: Kualitas, Strategi pemasaran dan Songket

\section{PENDAHULUAN}

Ekonomi kreatif tersebut digerakan oleh industri yang disebut sektor industri kreatif. Berdasarkan data bahwa di Indonesia peranan sektor industri kreatif dalam ekonomi nasional cukup signifikan dengan besar kontribusi terhadap PDB rata-rata tahun 2002 - 2006 adalah sebesar 6,3 \% atau setara dengan 104,6 Triliun rupiah (nilai nominal) (Pengembangan Ekonomi Kreatif Industri 2025:2).

Salah satu sub sektor indutri kreatif yang memiliki potensi besar untuk dikembangkan dan sebagai komoditas ekspor adalah sub sektor kerajinan. Dalam beberapa tahun terakhir produk kerajinan memberikan kontribusi yang cukup positif bagi ekspor: "Nilai ekspor kerajinan tangan pada tahun 2012 mendekati 700 juta dolar Amerika. Sedangkan pada tahun sebelumya, yaitu pada tahun 2011 nilai ekspor mencapai 660 juta dolar Amerika. Artinya terdapat peningkatan sebesar 7 persen. (Kompas, 22 Mei 2013 : 34). Dengan demikian sub sektor tersebut memiliki prospek cukup cerah sehingga perlu ditingkatkan lebih optimal karena potensinya di Indonesia tersedia banyak.

Kain tenun Songket adalah salah satu produk kerajinan khas Palembang yang memiliki nilai ekonomi cukup tinggi, segmen pasar yang beragam mencakup segmen kalangan menengah hingga atas dan sebagainya. Namun seiring perkembangan jaman dan perekonomian global yang bersifat kompetitif, maka terdapat gejala tingkat penjualan kain tenun tersebut tidak banyak berkembang. 
Hal ini disebabkan berbagai faktor, terutama semakin berkurangnya perajin sebagai akibat minimnya upah perajin Songket jika dibandingkan dengan upah sebagai pekerja buruh pabrik. Selama ini industri kerajinan kain tenun Songket tengah menghadapi kendala dalam mendapatkan tenaga kerjanya karena banyak pekerja yang diserap oleh industri besar dengan upah yang lebih besar dan stabil.

Sebagaimana umumnya usaha kerajinan tradisional yang hampir seluruh proses pekerjaannya bersifat manual atau semi masinal, maka peranan ketrampilan tangan perajin sangat dominan. Hal yang sama juga dilakukan dalam proses menenun kain Songket yang dikerjakan dengan peralatan sederhana bukan mesin. Adanya keterbatasan alat yang masih sederhana tersebut dan lebih banyak mengandalkan tenaga kerja manusia menyebabkan proses produksinya memerlukan ketelitian tinggi dan waktu yang cukup lama.

Untuk menyelesaikan satu lembar kain ukuran $200 \mathrm{~cm}$ x $90 \mathrm{~cm}$ dan selendangnya ukuran 200 $\mathrm{cm}$ x $60 \mathrm{~cm}$ diperlukan proses pengerjaan berkisar antara 2-3 pekan. Sedangkan unutuk sebuah kain tenun Songket yang berkualitas baik dengan bahan benang sutra atau emas akan memerlukan waktu pengerjaan lebih lama lagi karena memerlukan banyak proses, maupun ketelitian tingggi dikarenakan motifnya yang rumit. Memang pada saat ini di pasar terdapat juga kain tenun Songket produksi pabrik tapi kualitasnya lebih rendah jika dibandingkan buatan tangan tersebut. Harganya pun berbeda jauh karena jenis tersebut adalah produksi missal atau pabrikan.

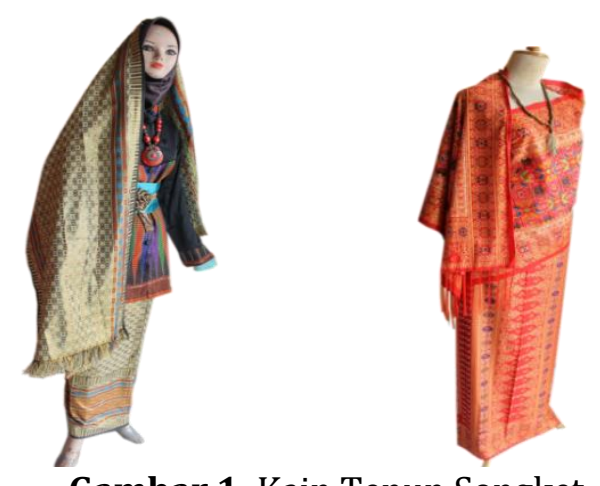

Gambar. 1 Kain tenun Songket yang berfungsi sebagai pakain adat khas Palembang. Sebuah produk kerajinan tradisional yang memiliki nilai-nilai historis dan simbolis bagi masyarakatnya sehingga perlu dikembangkan keberadaannya.

Salah satu sentra kain tenun Songket yang terkenal terdapat di Desa Gunung Batu, Kecamatan Cempaka, Kabupaten OKU Timur. Jarak kedua mitra tersebut dari kota Palembang $\pm 120 \mathrm{~km}$. Di Sentra tersebut terdapat \pm 50 perajin wanita yang memproduksi kain tenun Songket. Mereka adalah para perajin industri rumahan yang sebagian besar berpengalaman dan terdiri dari beberapa kelompok usaha dan melibatkan sanak keluarganya dalam bekerja.

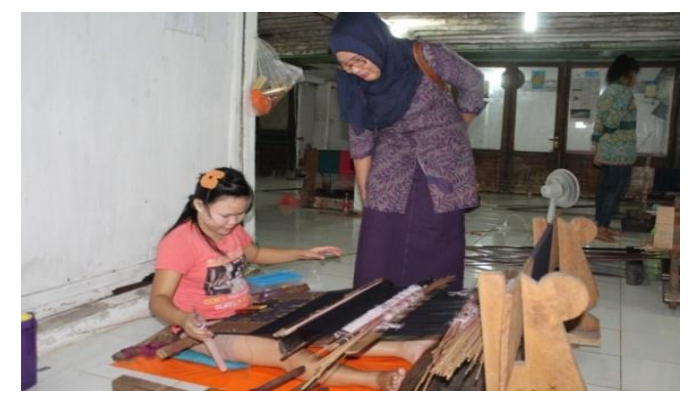

Gambar 2. Suasana tempat kerja kain tenun Songket yang masih bersifat tradisional dengan menggunakan alat-alat sederhana namun mampu menghasilkan produk yang bermutu tinggi

Dalam program kemitraan ini, pihak tim pengabdian pada masyarakat Universitas Indo Global Mandiri (UIGM) bermaksud menjalani kemitraan dengan kelompok perajin di bawah pimpinan Ibu Aisyah (50 tahun) yang memiliki anggota \pm 25 orang perajin. Mitra yang kedua adalah kelompok 
yang dipimpin oleh Ibu Ayu Ning (55 tahun) yang memiliki anggota \pm 20 perajin. Ibu Ayu Ning juga berperan sebagai pengepul untuk dijual ke pasar Hero maupun memasok ke beberapa toko di kota Palembang. Dengan harga antara Rp.400.000,- s.d Rp.500.000,-/helai tergantung dari kualitas produknya

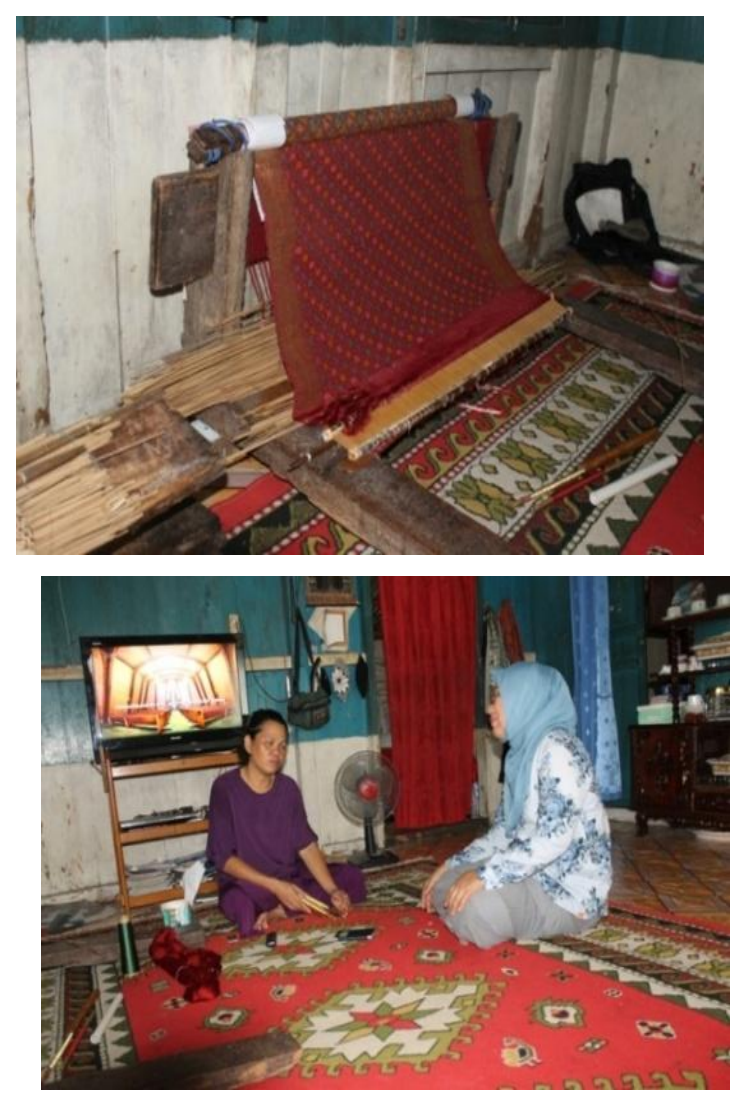

Gambar 3. (Atas) Kain tenun Songket motif "Bunga Pacar" yang menuntut ketelitian tinggi dan lazim digunakan pengantin. Harganya Rp. 4.000.000,-/ helai yang dikerjakan selama \pm 1 bulan.

(Bawah) Perajin kain tenun Songket Eni Sutarni (50 th) saat diwawancara oleh penulis.

Pemilihan kedua mitra tersebut dengan pertimbangan bahwa keduanya merupakan kelompok besar yang memiliki jumlah anggota banyak, produktivitas tinggi, kualitas produknya cukup baik dan memiliki pengalaman puluhan tahun. Diharapkan program kerjasama kemitraan tersebut dapat berjalan dengan baik dan dapat memberikan kontribusi positif bagi kedua belah pihak, khususnya bagi perajin mitra.

Mengenai upah perajin bervariasi disesuaikan dengan kualitas pekerjaan dan tingkat kesulitannya. Rata-rata upah pekerjaan borongan wanita perajin tersebut berkisar Rp. 200.000,- s.d Rp. 300.000,- / per helai dengan waktu pengerjaan sekitar 5-7 hari. Upah borongan di atas biasanya untuk jenis kain yang kualitasnya rendah dan dijual di pasar-pasar. Harga kain tenun Songket bervariasi antara Rp. 500.000,- hingga Rp. 40.000.000,-/helai. Harga yang disebutkan terakhir adalah kain tenun Songket berkualitas tinggi dengan menggunakan bahan sutra kualitas baik dan benang emas. Umumnya jenis kain tenun Songket ini hanya mengalami kerusakan pada bagian benangnya saja sedangkan benang emasnya masih utuh. Sehingga perlu dilakukan pekerjaan "bongkar-pasang", yaitu dengan mengganti benang yang lapuk dan memanfaatkan kembali benang emasnya yang sudah tua yang disebut "emas jantung". Proses produksi ulang ini membutuhkan waktu lama bahkan hingga berbulan-bulan tetapi upah kerjanya pun besar. Kain tenun Songket kualitas tinggi mampu bertahan ratusan tahun dan harganya pun ratusan juta karena termasuk jenis klasik. 


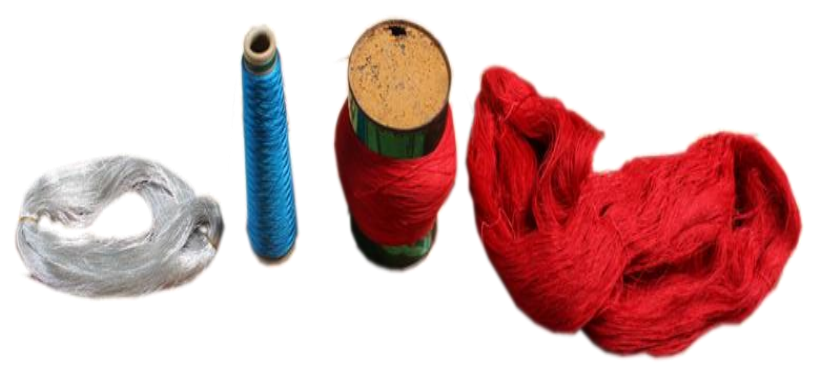

Gambar 4. Bahan baku benang sutra yang sebagian besar adalah benang impor karena kualitasnya lebih baik dibandingkan dengan yang local.

Pada umumnya para perajin kain tenun Songket mendapatkan upah yang minim jika dibandingkan dengan waktu kerja yang mereka habiskan untuk memproduksinya. Faktor minimnya upah dan tingkat produktivitas yang rendah dapat berdampak terhadap pada kualitas produknya, yaitu terbatas pengerjaan motif-motif yang relatif sederhana atau mudah pengerjaannya, tingkat kerapihannya rendah, bahan baku menggunakan benang lokal dan sebagainya. Jenis produk di atas biasanya untuk dipasarkan di pasar-pasar yang berada di kota Palembang.

Di dalam merespon permasalahan di atas, maka program Ipteks bagi masyarakat (IbM) akan difokuskan terhadap beberapa masalah sebagai berikut:

1. Manajemen produksi melalui peningkatan keterampilan teknis perajin di kedua mitra. Dasar pemikirannya bahwa kedua mitra tersebut menghadapi kesulitan dalam hal tenaga kerja perajinnya. Selain itu, terdapat keterbatasan ketrampilan perajin, terutama kalangan perajin muda yang belum banyak pengalaman.

2. Manajemen pemasaran berbasiskan internet agar segmen pasarnya lebih luas. Selama ini kedua mitra banyak memasok ke pasar-pasar di kota Palembang yang segmen pasar nya yang terbatas. Melalui inovasi pemasaran baru tersebut diharapkan kedua mitra mampu memperluas segmen pasarnya, termasuk pasar-pasar baru di luar Palembang.

3. Diversifikasi produk melalui desain varian-varian baru. Dasar pemikirannya bahwa sebuah motif dapat meningkatkan harga jual kain tenun Songket maupun upah perajinnya. Selama ini sistem pengupahan maupun penetapan harga jual kain tenun Songket juga tergantung motifnya. Semakin rumit, banyak ornamen dan sulit pengerjaannya, maka upahnya pun lebih tinggi dan harga jualnya lebih mahal.

Program-program di atas akan diimplementasikan melalui kegiatan pelatihan atau workshop dengan fasilitatornya dari pihak tim pengabdian UIGM Palembang.

Tujuan program IbM ini adalah sebagai berikut:

1. Mengembangkan tenaga kerja perajin yang mulai minim keberadaannya melalui program pelatihan ketrampilan.

2. Mengembangkan pemasaran produk melalui penjualan berbasis internet, yaitu sistem on line marketing.

3. Mengembangkan diversifikasi produk dengan cara menciptakan motif-motif baru yang lebih bervariasi.

Selama ini proses seperti di atas sering dilakukan oleh para pemilik usaha kain tenun Songket agar motif-motifnya lebih bervariasi dan sekaligus mengembangkan desain motifnya. Pada dasarnya melalui program pengembangan IbM di atas diharapkan kedua mitra mamupun sentra kerajinan kain tenun Songket di desa Gunung Batu dapat lebih berkembang.

\section{METODE PELAKSANAAN PENGABDIAN}

Pelaksanaan program kemitraan tersebut terdiri dari 3 jenis program, yaitu:

1. Manajemen pemasaran sederhana dengan menggunakan medium on line marketing. 


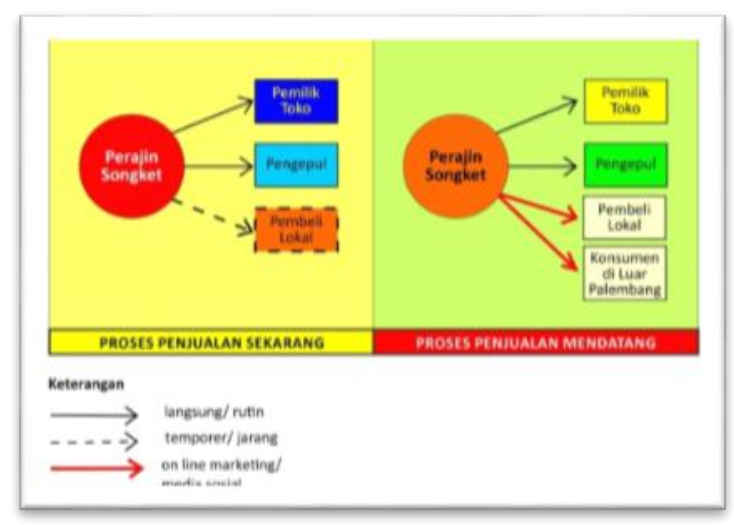

Gambar 5. Metode Pelaksanaan

2. Pengembangan teknis ketrampilan perajin kain tenun Songket karena terdapat kesulitan dalam hal tenaga perajin saat ini.

3. Pengembangan desain motif dengan cara modifikasi dari motif yang sudah ada atau lama.

\section{HASIL DAN PEMBAHASAN}

\subsection{Permasalahan Mitra}

Setelah melakukan survey awal ke sentra perajin kain tenun Songket di desa Gunung Batu, Kecamatan Cempaka, Kabupaten OKU Timur pengabdian masyarakat UIGM memperoleh beberapa gambaran permasalahan umum yang mereka hadapi selama ini di dalam menjalankan usahanya tersebut. Permasalahan yang dihadapi oleh kedua mitra dapat diklasifikasikan sebagai berikut: Permasalahan pokok yang dihadapi adalah mengenai SDM para perajinnya yang perlu ditingkatkan dalam hal ketrampilan teknisnya. Aspek tersebut berkaitan erat dengan kualitas produk maupun pendapatan perajinnya. Disamping itu, pasar global yang kompetitif telah mendorong persaingan dalam aspek kualitas dan ketrampilan. Beberapa produk-produk kerajinan produksi anggota ASEAN memiliki kualitas lebih baik dibandingkan produk produksi Indonesia sehingga kelemahan ini perlu segera ditangani secara seksama.

Permasalahan lainnya adalah dalam hal kerjasama pengembangan manajemen pemasaran berbasiskan internet. Pertimbangannya bahwa kompetensi dan pengalaman anggota tim UIGM selama ini adalah dalam hal pemasaran, termasuk penguasaan dalam hal pemasaran on line cukup banyak. Sehingga proses transfer teknologi tersebut sangat memungkinkan.

\subsection{Solusi yang Ditawarkan}

Dalam program kemitraan ini kedua belah pihak setuju untuk melakukan beberapa program kegiatan berikut:

1. Peningkatan ketrampilan SDM perajin kain tenun Songket di kedua kelompok mitra. Pihak TPP UIGM akan bertindak sebagai fasilitator teknis dan mengorganisasikan pelatihan bagi para perajin. Bertindak sebagai fasilitator teknisnya adalah perajin senior dan berpengalaman. Jumlah perajin yang akan mendapat pelatihan ketrampilan tersebut masing-masing mitra \pm 10 orang dengan kualifikasi perajin pemula.

2. Transfer teknologi dengan cara mengembangkan sistem pemasaran berbasis internet yaitu on line marketing agar kedua mitra tersebut dapat memperluas pemasarannya tidak hanya sebatas memasok pasar-pasar di Palembang tetapi juga di luar kota tersebut. Pihak TPP UIGM akan menerapkan sistem tersebut termasuk memfasilitasi web site kedua mitra.

3. Melakukan diversifikasi produk motif kain tenun Songket agar lebih bervariatif dan menarik. Dengan cara melakukan modifikasi motif-motif lama dengan memberikan sentuhan visual baru, modern atau masa kini. Tujuannya agar produk kedua mitra lebih beragam atau banyak pilihan bagi konsumen.

4. Melakukan inovasi dengan memberikan kemasan dus karton atau label pada produknya agar lebih menarik dan kesannya mahal. Bahwa peranan sebuah kemasan atau label pada sebuah 
produk sangat bermanfaat dan dapat memberikan sebuah nilai tambah. Meskipun hanya bersifat kecil penambahan tersebut namun hal ini adalah sebuah tindakan inovatif.

\subsection{Kegiatan Yang Dilaksanakan}

Adapun kegiatan yang dilakukan dari program IbM antara Universitas Indo Global Mandiri dengan perajin kain tenun Songket di Desa Gunung Batu, Kecamatan Cempaka, Kabupaten OKU Timur:

1. Keterampilan bagi para perajin sejumlah 4 perajin dari 2 kelompok mitra.

Jenis Pelatihan : Keterampilan menenun motif baru

Jumlah Motif : 2 motif baru

Bahan Baku : Benang Tenun Lokal, Sutra Lokal dan Sutra Impor

Waktu Pelatihan : 1 pekan

Lokasi Pelatihan : Sentra perajin Desa Gunung Batu

2. Desain web sebagai medium pemasaran on line marketing produk-produk kedua mitra. Fungsi web sebagai display atau katalog produk. Sedangkan sistem pemesanan dan pembayarannya menggunakan media komunikasi lain atau media sosial

Jenis Medium : : Web/ on line marketing

Jumlah Medium : 2 web dengan masing- masing mitra 1 web

Masa Penggunaan : 1 tahun

3. Desain motif kain tenun Songket baru sebagai salah satu program diversifikasi produk, khususnya motif.

Jumlah Desain : 2 motif hasil modifikasi dari motif lama atau yang sudah ada kedua mitra

Jenis Tenunan : Tenun bahan kain sutra local dan sutra impor

\section{KESIMPULAN}

Berdasarkan hasil dari pengabdian iptek bagi masyarakat yang telah dilaksanakan bahwa tenaga perajin songket sudah memiliki kemapuan yang cukup untuk dapat menghasilkan songket yang berkualitas dan berdaya jual yang tinggi. Perajin songket juga telah berhasil mendisversifikasikan produk songket menjadi produk berupa tas.

Perajin juga telah memahami tentang pentingnya promosi dan pemasaran melalui media website. Mengingat daerah desa Gunung Batu yang cukup jauh dari kota palembang dengan adanya website maka perajin bisa menjualkan songket langsung pada pelanggan.

\section{DAFTAR PUSTAKA}

Drucker, Peter F. 1994. Inovasi dan Kewirausahaan, Terjemahan. Jakarta: Penerbit Erlangga.

Drucker, Peter, F. 2002. The Dicipline of Innovation. Harvard: Harvard Business School Publishing Corporation

Gustami, S.P. Seni Kriya di Indonesia Dalam Konteks Budaya Bangsa. Makalah Seminar, 15 April 2003.

Jones, John Chris. 1992. Design Methods, Second edition. New York: Van Nostrand Reinhold.

Lundsörm, Anders. 2009. The Role of SMEs and Entrepreneurship in A Globalized Economy. Stockholm: The Globalization Council.

Natawiria, Asep Suryana. Developing Creative Industries to Build Competitive Nation in Indonesia, Case Study: Korea. Makalah Seminar, 2010: Bandung: Universitas Pasundan.

Sagir, Soeharsono. 2011. Ekonomi Berpihak Kepada Rakyat, Pro Poor, Pro Job, Pro Growth. Bandung: Asosiasi Ilmu Politik Indonesia (AIPI).

Walker, John A. 1989. Design History and the History of Design. London: Pluto Press.

-------Lahan Wirausaha dalam Industri Kreatif, Kompas, 22 Mei 2013, hal. 3 